\title{
ІНКЛЮЗИВНЕ НАВЧАННЯ У ВИЩИХ НАВЧАЛЬНИХ ЗАКЛАДАХ І-ІІ РІВНІВ АКРЕДИТАЦІЇ ЯК ШЛЯХ ДО САМОРЕАЛІЗАЦІї
}

\author{
О. Н. Литвинова ${ }^{1}$, I. Р. Стадницька ${ }^{2}$ \\ ${ }_{1}^{1}$ ДвНЗ «Тернопільський державний медичний університет \\ імені І. Я. Горбачевського МОз Украӥни» \\ ${ }^{2}$ ТзОВ Медичний коледж «Монада», м. Львів
}

У статті показано провідну роль інклюзивного навчання у вищих навчальних закладах I-II рівнів акредитації із певною інклюзивною часткою в процесі самореалізації осіб з особливими освітніми проблемами.

\section{INCLUSIVE EDUCATION IN HIGHER EDUCATIONAL INSTITUTES OF I-II ACCREDITATION LEVELS AS A WAY TO SELF-REALIZATION}

\author{
O. N. Lytvynova1 ${ }^{1}$ I. R. Stadnitskaya ${ }^{2}$ \\ ${ }^{1}$ I. Horbachevsky Ternopil State Medical University \\ ${ }^{2}$ Basic Department of the LTD Medical College "Monada", Lviv
}

The article shows the leading role of inclusive education in higher educational institutions of I-II accreditation levels with a certain inclusive part in the process of self-realization of people with special educational problems.

Вступ. У період входу України до європейської спільноти іде пошук шляхів активізації усвідомлення сутності окремої людини в суспільстві, її значущості, самореалізації, суспільної корисності. Особливо ці питання актуальні для людей з особливими освітніми потребами. Саме на етапі становлення особи задоволення її освітніх потреб є тією базою, яка визначатиме все подальше життя індивіда. Актуальним на сьогодні $\epsilon$ не відособлення людини з певними проблемами у здоров'ї, а саме ії̈ соціалізація гарантуватиме здорові відносини у суспільстві. Цим питанням і присвячена наша робота [7].

Основна частина. Інклюзивне навчання (англ. inclusive education) - буквально означає «особливе навчання» і передбачає, що учні чи студенти із особливими потребами будуть прийняті до загальноосвітнього середовища за місцем їхнього проживання чи за іншого вибору на загальних основах, що, практично, становитиме альтернативу інтернатній системі (коли дітей з особливими потребами відокремлювали від інших дітей) та навчанню вдома.

ЮНЕСКО визначає інклюзивне навчання як «процес звернення і відповіді на різноманітні потреби учнів через забезпечення їхньої участі в навчанні,

(с) О. Н. Литвинова, І. Р. Стадницька, 2018 культурних заходах і житті громади, та зменшення виключення в освіті та навчальному процесі» [2].

Інклюзивна освіта - це не лише створення доступного освітнього середовища для дітей з особливими освітніми потребами, а й рівних можливостей для всіх категорій дітей. Головне завдання інклюзії полягає в тому, щоб діти не відчували себе особливими, щоб на рівні з іншими вони брали участь у навчальному, виховному, розважальному процесах. Найважливіше завдання - дати їм можливість проявити свою успішність відповідно до власних здібностей та таланту [3].

Здобуття особами з особливими освітніми потребами чи інвалідністю вищої освіти (фахова підготовка) здійснюється у вищих навчальних закладах I-IV рівнів акредитації різних форм власності та відомчої належності, зокрема й у середніх спеціалізованих навчальних закладах (коледжах) України [4].

Навчання студентів з особливими освітніми потребами чи інвалідністю у коледжах здійснюється як у складі спеціальних навчальних груп, так і у складі змішаних навчальних груп разом із звичайними студентами [5].

Здобуття вищої освіти абітурієнтом з особливими освітніми потребами чи інвалідністю зазвичай повинно починатися із довузівської підготовки. Головною 
іiї метою є предметна підготовка до вступних іспитів та адаптація до навчання і життєдіяльності в незвичних умовах навчального закладу [4]. Однак, через здебільшого платний характер навчання, відсутність спеціально розроблених методик та належним чином підготовлених викладачів, можливість проходження цієї підготовки особами з особливими освітніми потребами чи інвалідністю (особливо із малозабезпечених сімей) фактично згорнута. Наслідком цього $€$ відмінність рівня вступної підготовки таких осіб від рівня підготовки решти абітурієнтів.

Враховуючи те, що можливості доступу до освіти в осіб з особливими освітніми потребами чи інвалідністю та здорових громадян відрізняються (головним чином через нижчий рівень матеріального забезпечення та загальноосвітньої підготовки), законодавством України передбачено для них ряд пільг при вступі до ВНЗ І-ІІ рівнів акредитації. Так, згідно з умовами прийому до ВН3, у тому числі коледжів, передбачено зарахування інвалідів I та II груп та дітей-інвалідів віком до 18 років, яким не протипоказано навчання за обраним напрямом (спеціальністю) поза конкурсом при поданні сертифікатів Українського центру оцінювання якості освіти (при одержанні оцінок на вступних випробуваннях не нижче встановленого рівня). Крім того, згідно з умовами прийому до ССНЗ за рекомендацією органів охорони здоров'я та соціального захисту населення приймальна комісія повинна розглядати питання про можливість зарахування до СCH3 понад державне замовлення за результатами співбесіди з правом на навчання за місцем проживання інвалідів, які не спроможні відвідувати навчальний заклад, а також зобов'язана створити умови для проходження ними курсу навчання за екстернатною чи дистанційною формами [2].

За інших рівних умов переважне право на зарахування до ВН3 мають інваліди та діти з малозабезпечених сімей, в яких обоє батьків - інваліди; один із батьків - інвалід, а інший помер; одинока матір - інвалід чи батько - інвалід, який виховує дитину без матері.

Під час навчання зазначеним категоріям громадян стипендія та пенсія (державна соціальна допомога інвалідам із дитинства і дітям-інвалідам) виплачуються у повному обсязі.

Міністерством освіти України постійно здійснюється цілеспрямована діяльність щодо забезпечення громадянам з особливими освітніми потребами чи інвалідністю можливості здобуття вищої освіти. Так, на виконання розпорядження Кабінету Міністрів України від 16.10.2008 р. № 1252-р., яким схвалено Комплексний план дій з розвитку освіти в Україні на період до 2012 р., передбачено адаптацію системи вищої освіти до норм, стандартів та основних принципів держав членів ЄС; забезпечення особистісно-орієнтованого навчання осіб з особливими освітніми потребами чи інвалідністю та видання спеціальних підручників, наочно-дидактичних посібників для осіб з інвалідністю; запровадження у вищих навчальних закладах психолого-педагогічної підтримки та соціального супроводу студентів-інвалідів; забезпечення цілісного підходу до створення належних умов для здобуття освіти такими особами у вищих навчальних закладах незалежно від їх типу, підпорядкування і форми власності. На виконання зазначеного Плану дій Інститутом інноваційних технологій і змісту освіти Міносвіти України розробляються нові державні стандарти для напряму «Корекційна освіта» (за нозологіями).

Питання доступності для осіб з особливими освітніми потребами чи інвалідністю середньої спеціалізованої освіти продовжує на сьогодні являти собою гостру соціальну проблему [1].

Розширення доступності освіти для осіб з особливими освітніми потребами чи інвалідністю (насамперед інклюзивної освіти), інтеграція їх в освітнє та соціальне середовище ускладнюється цілим рядом проблем, що мають різний масштаб та характер.

Динаміку чисельності осіб з особливими освітніми потребами чи інвалідністю, які навчаються у ВН3 I-IV рівнів акредитації, наведено на рисунку 1.

Основними проблемами доступності до вищої освіти для осіб з особливими освітніми потребами чи інвалідністю (насамперед інклюзивної освіти), інтеграція їх в освітнє та соціальне середовище, які ще й мають різний масштаб та характер, $є$ :

- недостатній рівень якості загальної середньої освіти інвалідів, що створює перешкоди при їх вступі до ВНЗ І-ІІ рівнів акредитації;

- відсутність умов для сумісництва фахової підготовки інвалідів та їх медичної реабілітації;

- недостатня розробленість нормативно-правової бази щодо освіти інвалідів;

- незабезпеченість безбар'єрного архітектурного середовища при навчанні інвалідів у коледжах;

- недостатній рівень забезпечення студентів-інвалідів адаптивними технічними засобами навчання (різноманітним сурдо-, тифлотехнічним та іншим адаптивним обладнанням); 


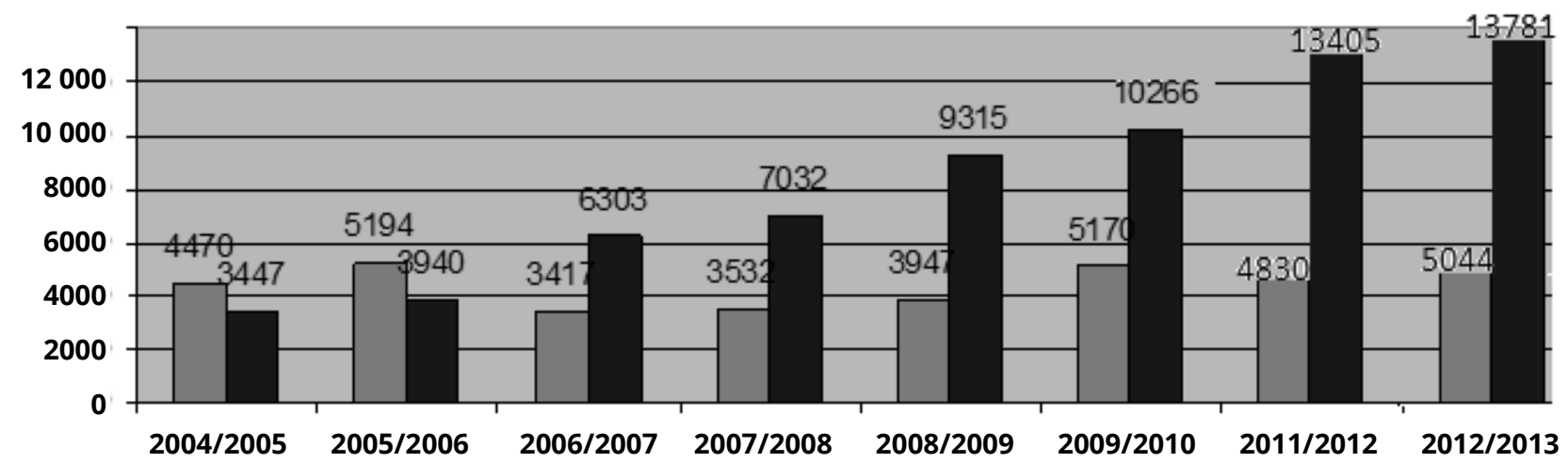

$\square$ Чисельність студентів-інвалідів у вищих навчальних закладах I-II рівнів акредитації

Нисельність студентів-інвалідів у вищих навчальних закладах III-IV рівнів акредитації

Рис. 1. Чисельність студентів, які мають інвалідність, у вищих навчальних закладах I-IV рівнів акредитації.

- недостатній рівень забезпечення студентів-інвалідів навчально-методичною літературою, адаптованою до їх психофізіологічних потреб;

- недостатній рівень розвитку суспільної свідомості щодо розуміння проблем та потреб інвалідів;

- недостатня консолідація зусиль інвалідів (в силу як суб'єктивних, так і об'єктивних обставин) у частині

\section{СПИСОК ЛІТЕРАТУРИ}

1. Дзеркало інклюзивної освіти в Україні: про стан інклюзивного навчання 2017-2018 роки.

2. Про освіту осіб, які потребують корекції фізичного та (або) розумового розвитку (спеціальну освіту) : Законопроект України.

3. Інвалідність та суспільство : навчально-методичний посібник / Л. Ю. Байда, О. В. Красюкова-Еннс, С. Ю. Буров [та ін.] ; за заг. ред. Л. Ю. Байди, О. В. Красюкової-Еннс. К., 2012. -216 c.

4. Інклюзивна освіта: стан і перспективи розвитку в Україні : науково-методичний збірник. - К. : ФО-П Придатченко П. М., 2007. - 336 с. відстоювання своїх прав, у тому числі й права на здобуття освіти.

Висновки. Визначено основні проблеми інклюзивної вищої освіти для осіб з особливими освітніми потребами чи інвалідністю.

5. Лорман Т. Інклюзивна освіта. Підтримка розмаїття у класі : практ. посіб. ; пер. з англ. / Т. Лорман, Дж. Депплер, Д. Харві. - К. : СПД-ФО Парашин І. С., 2010. - 296 с.

6. Лорман Т. Освіта дітей з особливими потребами: пошуки та перспективи. Інклюзивна освіта. Підтримка розмаїття у класі : практ. посіб. ; пер. з англ. / Т. Лорман, Дж. Депплер, Д. Харві. - К. : СПД-ФО Парашин І. С., 2010. 296 c.

7. Саламанкська декларація і рамки дій з освіти осіб з особливими потребами (1994р.) [Електронний ресурс]. - Режим доступу : http://www.un.org/ru/documents/ decl_conv/declarations/pdf/salamanka.pdf. 